\title{
SALAH KAPRAH PEMAKNAAN KATA DALAM BAHASA INDONESIA DAN UPAYA PERBAIKANNYA
}

\author{
Syahru Ramadan ${ }^{\mathrm{a}}$, Sonny Affandi ${ }^{\mathrm{b}}$, Yeti Mulyatic \\ ${ }^{a}$ Universitas Pendidikan Indonesia \\ ${ }^{\mathrm{b}}$ Universitas Pendidikan Indonesia \\ ${ }^{c}$ Universitas Pendidikan Indonesia \\ syahru.ramadan.unm@upi.edu
}

\begin{abstract}
Abstrak
Salah Kaprah Pemaknaan Kata dalam Bahasa Indonesia dan Upaya Perbaikannya (Studi Kasus Pengguna Bahasa Indonesia). Penelitian ini bertujuan untuk (1) mendeskripsikan persepsi pengguna bahasa Indonesia dalam memaknai kata-kata yang sering disalahkaprahkan dan (2) mendeskripsikan upaya memperbaikinya. Penelitian ini merupakan penelitian deskriptif kualitatif. Instrumen yang digunakan adalah peneliti dan angket. Metode penyajian datanya adalah metode simak dengan teknik simak bebas cakap dan catat. Hasil analisis data menunjukkan bahwa (1) persepsi pengguna bahasa Indonesia terhadap pemaknaan 12 kata yang sering disalahkaprahkan yaitu di antara 12 kata tersebut, hanya 2 kata yang dimaknai sesuai dengan KBBI oleh sebagian besar responden dan 10 kata lainnya dimaknai keliru. Kata-kata yang dimaknai sesuai dengan KBBI adalah absen dan kosong, sedangkan yang dimaknai keliru adalah acuh, bergeming, absensi, nuansa, gahar, seronok, empek-empek, carut-marut, notulen, dan rempong. Adapun beberapa penyebab pemaknaan tersebut adalah sering mendengar dari orang lain (masyarakat), melihat pada media, menjadi kebiasaan sehari-hari, dan melihat makna pada kamus. (2) Upaya memperbaiki pemaknaan itu dengan melalui upaya revitalisasi bahasa Indonesia.

Kata-kata Kunci: Salah Kaprah, Pemaknaan Kata, Pengguna Bahasa Indonesia.
\end{abstract}

\section{Abstract}

Misguided in Meaning of Words of Indonesian Language and its Improvement Efforts (Case Study on Indonesian User Community). This study aims to (1) describe the perceptions of Indonesian users in interpreting the words that are often misunderstood and (2) to describe the effort to improve them. This research is a qualitative descriptive study. The instruments used are researchers and questionnaires. The method used to presenting data is a observation method with uninvolved conversation observation technique and writing technique. The result of data analysis shows that (1) Indonesian language user perception on 12 word meanings which is often misused is between 12 words, only 2 words are interpreted according to KBBI by most respondents and 10 other words are interpreted wrongly. Words that are interpreted in accordance with KBBI are absen and kosong, while the interpreted erroneously are acuh, bergeming, absensi, nuansa, gahar, seronok, empek-empek, carut-marut, notulen, and rempong. As for some of the causes of meaning are often heard from others (the public), looking at the media, into daily habits, and see the meaning in dictionary. (2) Efforts to improve that by revitalize the Indonesian language.

Keywords: Misguided, Words meaning, Indonesian User Community. 


\section{PENDAHULUAN}

Abad ke-21 dikenal sebagai abad globalisasi tahap ketiga. Dalam tahap ini ukuran dunia semakin mengecil dan memasuki peradaban baru yang bernama budaya maya (cybercultures). Tahap ketiga ini ditandai dengan kemajuan pesat dalam bidang teknologi informasi dan komunikasi. Tahap ini pula memengaruhi semua bidang kehidupan manusia, baik ekonomi, politik, pendidikan, bahkan bahasa. Bahasa sendiri, di dunia, sangat beraneka ragam dan Indonesia, sebagai salah satu negara di dunia, memiliki bahasa sendiri yang merupakan salah satu ciri khas yang membedakannya dengan kebanyakan negara lain. Bahasa tersebut adalah bahasa Indonesia.

Penggunaan bahasa Indonesia dewasa ini mulai terpinggirkan, dalam artian penghargaan terhadap bahasa Indonesia mulai rendah. Masyarakat Indonesia mulai lebih memilih bahasa Inggris dan lebih bangga berbahasa Inggris dibanding berbahasa Indonesia. Hal itu diakibatkan oleh pengaruh globalisasi dengan menjadikan bahasa Inggris sebagai lingua franca dunia yang membuat masyarakat dunia harus menguasainya demi mampu bersaing.

Melihat fenomena itu, sudah sewajarnya jika eksistensi bahasa Indonesia sebagai ciri khas kebanggaan bangsa Indonesia tetap harus dijaga, bahkan harus ditingkatkan. Akan tetapi, melihat potret penggunaan bahasa Indonesia, eksistensi bahasa Indonesia semakin memudar. Bahkan, Sartini (2014, hlm. 208) mengungkapkan bahwa bahasa Indonesia saat ini adalah bahasa yang kacau. Kekacauan itu terjadi pada tataran kosa kata, semantik, dan struktur. Hal itu disebabkan oleh beberapa hal, antara lain: (1) penggunaan bahasa Inggris secara berlebihan atau salah kaprah; (2) pelanggaran kaidah-kaidah bahasa Indonesia, baik di media massa maupun di tempat-tempat umum; (3) masuknya struktur kalimat bahasa daerah ke dalam bahasa Indonesia yang tidak sesuai dengan bahasa Indonesia yang benar; (4) meluasnya kecenderungan menggunakan akronim secara sewenang-wenang; (5) munculnya bahasa remaja yang disebut bahasa gaul dengan berbagai proses pembentukannya yang unik; dan (6) munculnya bahasa birokrasi yang memiliki tipe tersendiri yaitu singkat dengan jargon-jargon khusus.

Semua penyebab itu membuat pemahaman masyarakat Indonesia terhadap kaidah bahasa Indonesia yang benar semakin memudar. Bahkan, dalam penggunaan bahasa Indonesia sehari-hari, masyarakat Indonesia sering memunculkan dua bentuk kata yang 
saling berkompetisi penggunaannya (Setyadi, 2014, hlm. 74). Misalnya, pada kata merubah dan mengubah.

Selain itu, sering juga masyarakat Indonesia tidak bersumber pada kamus ketika memaknai kata. Sebagai contoh pada kata acuh. Sering dijumpai masyarakat Indonesia yang memaknai kata acuh dengan arti tidak peduli. Padahal, dalam kamus kata acuh bermakna peduli. Kesalahan itu jika dipahami sebagai kebenaran, maka akan berujung pada salah kaprah atau kesalahan yang telah dianggap sebagai kebenaran.

Jika masalah-masalah tersebut dibiarkan, maka akan membuat bahasa Indonesia semakin kacau dan bukan tidak mungkin eksistensi bahasa Indonesia akan menghilang di masa depan diakibatkan oleh kurangnya penghargaan masyarakat terhadap penggunaan bahasa Indonesia yang baik dan benar. Masyarakat menggunakan bahasa Indonesia seenaknya tanpa memperhatikan kaidah-kidah atau aturan-aturan kebahasaan.

Berangkat dari fenomena itulah peneliti membuat penelitian yang memotret fenomena kebahasaan dalam masyarakat pengguna bahasa Indonesia, khususnya dalam bidang semantik (pemaknaan kata). Penelitian ini bertujuan untuk mendeskripsikan persepsi pengguna bahasa Indonesia dalam memaknai kata-kata dalam bahasa Indonesia. Selain itu, akan dipaparkan juga upaya-upaya untuk mengatasi masalah tersebut dan mengembalikan eksistensi bahasa Indonesia yang baik dan benar.

\section{LANDASAN TEORI}

Adapun teori yang digunakan dalam penelitian ini adalah teori semantik yang lebih khusus kepada pergeseran dan perubahan makna. Pergeseran makna sendiri adalah gejala perluasan, penyempitan, pengonotasian, penyinestesiaan, dan pengasosiasian sebuah makna kata yang masih hidup dalam satu medan makna. Dalam pergeseran, makna rujukan awal tidak berubah atau diganti, tetapi mengalami perluasan atau penyempitan rujukan (Parera, 2004). Berbeda dengan pergeseran makna, perubahan makna berarti makna awal mengalami perubahan. Hal itu bisa diakibatkan oleh pergeseran makna tadi. Dengan demikian, antara pergeseran makna dan perubahan makna memiliki hubungan yang sangat erat dan tidak terpisahkan.

Pergeseran makna dan perubahan makna memiliki beberapa faktor yang menyebabkannya. Faktor-faktor tersebut antara lain: (1) Bahasa turun temurun dari generasi ke generasi dengan cara langsung atau tidak langsung. Misalnya, seorang anak selalu belajar bahasa dalam bentuk yang segar. Tanggapan seorang anak terhadap makna 
didasarkan pada konteks pemakaiannya. Kesalahan persepsi seorang anak yang tidak diperbaiki inilah penyebab awal pergeseran makna; (2) Kekaburan dan ketidakpastian makna. Ketidakakraban pemakai bahasa akan makna sebuah kata merupakan sumber dari kekaburan makna yang berakibat terjadinya pergeseran makna; (3) Kehilangan motivasi. Sepanjang sebuah kata tetap dengan kuat berpegang pada akar makna awal dan pada medan makna yang sama, maka pergeseran makna itu tidak terjadi. Namun sebaliknya, jika kata kehilangan motivasi makna awal, makna jadi berkembang dan tak terkendali; dan (4) Faktor salah kaprah juga mempermudah pergeseran dan perubahan makna. Salah kaprah merupakan kesalahan yang terjadi karena kebiasaan dengan sesuatu yang salah dan dibiarkan terus berjalan tanpa usaha perbaikan pemakainya. Salah kaprah ini sering ditemukan dalam bidang sosial yang menjadikan makna kata mengalami perluasan atau penyempitan (Ullman dalam Sumarsono, 2012, hlm. 251).

Berdasarkan dari beberapa penyebab pergeseran dan perubahan makna di atas, penelitian ini lebih berfokus pada faktor salah kaprah. Faktor tersebut sebenarnya tidak berdiri sendiri dan mendapat pengaruh dari faktor-faktor lain. Dengan demikian, tidak menutup kemungkinan jika dalam penelitian ditemukan penyebab terjadinya salah kaprah akibat dari faktor-faktor lain.

\section{METODE PENELITIAN}

Seperti pada penelitian-penelitian lain yang menggunakan pendekatan kualitatif dan menggunakan teori acuan dalam menganalisis data, maka dalam penelitian ini juga demikian. Berdasarkan judul penelitian ini, yakni "Salah Kaprah Pemaknaan Kata dalam Bahasa Indonesia dan Upaya Perbaikannya (Studi Kasus Pengguna Bahasa Indonesia)”, maka jenis penelitian ini termasuk penelitian deskriptif kualitatif yang bertujuan mendeskripsikan data berupa persepsi masyarakat pengguna bahasa Indonesia dalam memaknai kata-kata bahasa Indonesia.

Data dalam penelitian ini berupa kata-kata dan kalimat. Apabila ada angka dalam penelitian ini, hanya untuk mendukung pendeskripsian hasil penelitian. Data penelitian ini berupa persepsi dari tujuh puluh pengguna bahasa Indonesia dalam memaknai dua belas kata bahasa Indonesia. Sumber datanya sendiri adalah masyarakat pengguna bahasa Indonesia.

Instrumen penelitian ini adalah peneliti sendiri (human instrument), yang berfungsi sebagai pengumpul serta penganalisis data. Peneliti mengedepankan kemampuan 
memproses data secepatnya serta memanfaatkan kesempatan untuk mengklarifikasi data (Moleong, 2005, hlm. 171). Penelitian ini menggunakan alat bantu berupa perangkat lunak. Perangkat lunak yang dimaksud berupa angket mengenai kata-kata yang sering disalahkaprahkan maknanya beserta konteks kalimat yang mendukung makna leksilkal kata-kata tersebut. Berikut wujud angket yang digunakan.

Tabel 1. Kuesioner atau Angket Penelitian

\begin{tabular}{|c|c|c|c|c|}
\hline NO & KATA & S/TS & KONTEKS (KALIMAT) & $\begin{array}{l}\text { KONTEKS } \\
\text { (KALIMAT) }\end{array}$ \\
\hline 1 & Acuh & & $\begin{array}{l}\text { Kehadirannya relalu } \\
\text { diacuhkan dan diabaikan oleh } \\
\text { ayahnya sendiri. }\end{array}$ & $\begin{array}{l}\text { Sebagai tanda cintanya, } \\
\text { Zulham senantiasa } \\
\text { mengacuhkan istrinya. }\end{array}$ \\
\hline 2 & Bergeming & & $\begin{array}{l}\text { Messi diam tak bergeming } \\
\text { ketika melihat aksi Cristiano } \\
\text { Ronaldo. }\end{array}$ & \begin{tabular}{lr} 
Buffon selalu saja \\
bergeming \\
membatu dan \\
menerima bola sepakan \\
\multicolumn{2}{l}{ Cristiano Ronaldo. }
\end{tabular} \\
\hline 3 & Absen & & $\begin{array}{l}\text { "Saya absen dulu ya, anak- } \\
\text { anak!" teriak pak guru seraya } \\
\text { mengambil daftar hadir. }\end{array}$ & $\begin{array}{l}\text { Anak itu selalu saja } \\
\text { absen dalam pelajaran } \\
\text { matematika sehingga } \\
\text { nilainya rendah. }\end{array}$ \\
\hline 4 & Absensi & & $\begin{array}{l}\text { Absensi pegawai perusahaan } \\
\text { Podomoro menurun dan } \\
\text { mencapai } 5 \% \text { di tahun } 2016 \text {. }\end{array}$ & $\begin{array}{l}\text { Guru memberikan daftar } \\
\text { absensi kepada siswa di } \\
\text { kelas untuk diisi. }\end{array}$ \\
\hline 5 & Nuansa & & $\begin{array}{l}\text { Nuansa teror sangat terasa di } \\
\text { Paris selepas peledakan bom } \\
\text { oleh teroris. }\end{array}$ & $\begin{array}{l}\text { Warna merah marun dan } \\
\text { merah bata memiliki } \\
\text { nuansa yang kecil. }\end{array}$ \\
\hline 6 & Gahar & & $\begin{array}{l}\text { Pria itu menato seluruh } \\
\text { tubuhnya untuk menciptakan } \\
\text { kesan gahar pada dirinya. }\end{array}$ & $\begin{array}{l}\text { "Gahar pakaianmu } \\
\text { Ahmad agar bersih!" } \\
\text { seru ibu kepadaku. }\end{array}$ \\
\hline 7 & Kosong & & $\begin{array}{l}\text { Pertandingan sepak bola } \\
\text { antara Persib Bandung dan } \\
\text { PSM Makassar berakhir } \\
\text { dengan skor kosong-kosong. }\end{array}$ & $\begin{array}{l}\text { Keadaan hatinya kosong } \\
\text { selepas kehilangan } \\
\text { adiknya. }\end{array}$ \\
\hline 8 & Seronok & & $\begin{array}{l}\text { Suara wanita itu sangat } \\
\text { seronok dan menarik hati. }\end{array}$ & $\begin{array}{l}\text { Aksi seronok yang } \\
\text { dilakukan Ariel dan } \\
\text { Luna Maya tidak patut } \\
\text { untuk ditiru. }\end{array}$ \\
\hline 9 & $\begin{array}{l}\text { Empek- } \\
\text { Empek }\end{array}$ & & $\begin{array}{ll}\text { Fikri adalah salah seorang } \\
\text { pengusaha } & \begin{array}{l}\text { empek-empek } \\
\text { yang sukses. }\end{array}\end{array}$ & $\begin{array}{l}\text { Wanita itu selalu } \\
\text { merawat dan } \\
\text { memperhatikan empek- } \\
\text { empek yang tinggal di } \\
\text { samping rumahnya. }\end{array}$ \\
\hline 10 & $\begin{array}{l}\text { Carut- } \\
\text { marut }\end{array}$ & & $\begin{array}{l}\text { Karena kesal, dia } \\
\text { mengeluarkan carut-marut } \\
\text { yang diketahuinya. }\end{array}$ & $\begin{array}{l}\text { Presiden Joko Widodo } \\
\text { mengambil keputusan } \\
\text { tegas dalam menghadapi } \\
\text { carut-marut } \\
\text { perpolitikan Indonesia. }\end{array}$ \\
\hline
\end{tabular}




\begin{tabular}{|c|c|c|c|}
\hline 11 & Notulen & $\begin{array}{l}\text { Dalam setiap diskusi, seorang } \\
\text { moderator selalu didampingi } \\
\text { oleh seorang notulen. }\end{array}$ & $\begin{array}{lr}\text { Notulen hasil } & \text { rapat itu } \\
\text { diserahkan } & \text { oleh } \\
\text { sekretaris } & \text { kepada } \\
\text { direktur. } & \\
\end{array}$ \\
\hline 12 & Rempong & $\begin{array}{l}\text { Di dunia ini, banyak } \\
\text { perempuan rempong yang } \\
\text { gemar mengurusi urusan } \\
\text { orang lain. }\end{array}$ & $\begin{array}{l}\text { Karena rempong, Ali } \\
\text { tidak bisa ke mana- } \\
\text { mana. }\end{array}$ \\
\hline
\end{tabular}

Dalam penelitian ini, digunakan metode simak dengan teknik penyajian data simak bebas cakap dan catat. Digunakan metode simak karena merupakan penyimakan penggunaan bahasa. Istilah menyimak di sini tidak hanya berkaitan dengan penggunaan bahasa lisan, tetapi juga bahasa tulis (Mahsun, 2005, hlm. 92). Pengumpulan data menggunakan teknik simak bebas cakap dan dilanjutkan dengan teknik catat. Teknik ini dilakukan dengan cara mencatat dan memilah-milah unsur-unsur yang diteliti.

Kemudian, dalam penelitian ini, dilakukan beberapa langkah atau tahapan dalam menganalisis data, antara lain : 1) mendeskripsikan persepsi masyarakat pengguna bahasa Indonesia mengenai kata-kata yang disalahkaprahkan maknanya sesuai dengan angket yang telah disusun; 2) mendeskripsikan upaya-upaya untuk mengatasi kesalahan tersebut; dan (3) menarik simpulan atas permasalahan kesalahan atau salah kaprah dalam memaknai kata bahasa Indonesia. Semua makna kata dalam penelitian ini mengacu pada makna dalam KBBI (Kamus Besar Bahasa Indonesia) edisi IV dan V, baik daring maupun luring. Selanjutnya, untuk memperkuat keabsahan data dalam penelitian ini, peneliti melakukan pemeriksaan dengan serius membaca, mengecek, dan mengintensifkan analisis data.

\section{HASIL DAN PEMBAHASAN}

Deskripsi hasil penelitian ini disesuaikan dengan tujuan penelitian yaitu: (1) mendeskripsikan persepsi masyarakat pengguna bahasa Indonesia dalam memaknai katakata yang sering disalahkaprahkan; dan (2) mendeskripsikan upaya memperbaiki kesalahan pemaknaan tersebut.

\section{Persepsi Masyarakat Pengguna Bahasa dalam Memaknai Kata dalam Bahasa Indonesia}

Dalam penelitian ini dikumpulkan persepsi dari 70 responden pengguna bahasa Indonesia, yang terdiri atas 32 mahasiswa, 1 event organizer, 1 freelancer, 7 guru, 5 ibu 
rumah tangga, 6 karyawan swasta, 3 PNS, 4 siswa, 1 petani, 1 pustakawan, 1 satpam, dan 8 wiraswasta. Kata-kata yang dimaknai oleh mereka terdiri atas acuh, bergeming, absen, absensi, nuansa, gahar, kosong, seronok, empek-empek, carut-marut, notulen, dan rempong. Persepsi para pengguna bahasa Indonesia tersebut dituangkan dalam bentuk angket. Dari hasil angket tersebut, didapatkan beberapa penjelasan mengenai persepsi pengguna bahasa Indonesia dalam memaknai kata bahasa Indonesia, antara lain:

\section{Bentuk dan Pemaknaan Sesuai dengan KBBI}

Dari dua belas kata yang menjadi bahan pemaknaan oleh pengguna bahasa Indonesia, terdapat dua kata yang sebagian besar dimaknai sesuai dengan KBBI (Kamus Besar Bahasa Indonesia). Kata-kata tersebut adalah absen dan kosong. Pemaknaan katakata tersebut dijelaskan di bawah ini.

Dari tujuh puluh responden, 78,6\% di antaranya memaknai kata absen dengan arti tidak hadir. Hal itu terlihat dari pilihan mereka pada kalimat "Anak itu selalu saja absen dalam pelajaran matematika sehingga nilainya rendah" dalam angket. Kemudian, sebagian besar responden atau 70\% di antaranya memaknai kata kosong dengan arti hampa atau tidak ada. Hal itu terlihat dari pilihan mereka pada kalimat "Keadaan hatinya kosong selepas kehilangan adiknya".

Sebagian besar responden telah mamahami makna dari dua kata tersebut dengan benar. Pemaknaan kata absen dan kosong dari mereka sesuai atau sejalan dengan makna dalam KBBI. Makna absen dalam KBBI adalah tidak hadir dan makna kosong dalam KBBI adalah hampa atau tidak ada. Dengan demikian, kata kosong tidak lagi dapat dipadankan dengan kata nol.

\section{Bentuk dan Pemaknaan Tidak Sesuai dengan KBBI}

Dari dua belas kata yang menjadi bahan pemaknaan oleh pengguna bahasa Indonesia, terdapat sepuluh kata yang sebagian besar dimaknai keliru atau salah kaprah. Kata-kata tersebut adalah acuh, bergeming, absensi, nuansa, gahar, seronok, empekempek, carut-marut, notulen, dan rempong. Pemaknaan kata-kata tersebut dijelaskan di bawah ini.

Dari tujuh puluh responden, 55,7\% di antaranya memaknai kata acuh dengan arti tidak peduli. Hal itu terlihat pada pilihan mereka dalam kalimat "Kehadirannya selalu diacuhkan dan diabaikan oleh ayahnya sendiri” yang terdapat dalam angket. Sedangkan, 
44,3\% memaknai kata acuh dengan arti peduli, sebagaimana pilihan mereka pada kalimat "Sebagai tanda cintanya, Zulham senantiasa mengacuhkan istrinya." Dilihat dari konteks kedua kalimat, sangat jelas tergambar makna kata acuh pada masing-masing kalimat. Dengan melihat konteks tersebut para responden, sebagian besar, memaknai keliru kata acuh. Tidak mengherankan sebenarnya jika para responden memaknai acuh dengan makna yang keliru karena pemahaman mendasar sebagian masyarakat mengenai makna acuh seperti itu. Sering ditemukan dalam media, baik media massa cetak maupun elektronik yang memaknai kata acuh dengan arti tidak peduli. Pemahaman inilah yang diikuti oleh sebagian masyarakat dan membuat mereka keliru dalam memaknai kata acuh.

Selanjutnya, dari tujuh puluh responden, $75,7 \%$ di antaranya memaknai kata bergeming dengan arti bergerak, sebagaimana yang terlihat pada pilihan mereka dalam kalimat "Messi diam tak bergeming ketika melihat aksi Cristiano Ronaldo". Kemudian, 24,3\% memaknai kata bergeming dengan arti diam, sebagaimana yang terlihat dalam pilihan mereka pada kalimat "Buffon selalu saja bergeming dan membatu ketika menerima bola sepakan Cristiano Ronaldo.” Dilihat dari konteks kedua kalimat, sangat jelas tergambar makna kata bergeming pada masing-masing kalimat. Dengan melihat konteks tersebut para responden, sebagian besar, memaknai keliru kata bergeming. Umumnya responden selalu memasangkan kata tidak dengan kata bergeming. Padahal, jika rujukan makna yang dimaksud adalah diam, maka kata tidak sebelum kata bergeming tidak perlu ada. Bahkan, jika kata tidak diperadakan sebelum kata bergeming, maka akan merusak dan mengaburkan makna kata bergeming.

Selanjutnya, sebanyak 58,6\% dari tujuh puluh responden memaknai kata absensi dengan arti daftar hadir atau kehadiran. Hal itu terlihat dari pilihan mereka pada kalimat "Guru memberikan daftar absensi kepada siswa di kelas untuk diisi”. Kemudian, 37,4\% memaknai kata absensi dengan arti daftar tidak hadir atau ketidakhadiran. Hal itu terlihat pada pemilihan kalimat "Absensi pegawai perusahaan Podomoro menurun dan mencapai 5\% di tahun 2016". Dilihat dari konteks kedua kalimat, sangat jelas tergambar makna kata absensi pada masing-masing kalimat. Dengan melihat konteks tersebut para responden, sebagian besar, memaknai keliru kata absensi. Umumnya, para responden sering mengaitkan kata absensi dengan daftar hadir. Hal itu terjadi karena pemakaian makna tersebut dalam kehidupan sehari-hari. Sering ditemukan dalam sekolah maupun kampus kebiasaan menyebut daftar hadir sebagai absensi. Hal itu dilakukan oleh guru, maupun 
siswa. Hal tersebutlah yang membuat pemahaman makna absensi menjadi mendarah daging, walaupun sebenarnya keliru dan tidak sesuai dengan makna dalam KBBI (Kamus Besar Bahasa Indonesia).

Selanjutnya, sebanyak $64,3 \%$ dari responden memaknai kata nuansa dengan arti suasana. Hal itu tergambar pada pilihan mereka dalam kalimat "Nuansa teror sangat terasa di Paris selepas peledakan bom oleh teroris". Selebihnya, yaitu 35,7\%, memaknai kata nuansa dengan arti perbedaan atau variasi. Hal itu terlihat pada pilihan mereka dalam kalimat "Warna merah marun dan merah bata memiliki nuansa yang kecil" yang terdapat pada angket. Dilihat dari konteks kedua kalimat, sangat jelas tergambar makna kata nuansa pada masing-masing kalimat. Dengan melihat konteks tersebut para responden, sebagian besar, memaknai keliru kata nuansa.

Selanjutnya, dari tujuh puluh responden, $77,1 \%$ di antaranya memaknai gahar dengan arti galak atau garang. Hal itu terlihat dari pilihan mereka pada kalimat "Pria itu menato seluruh tubuhnya untuk menciptakan kesan gahar pada dirinya". Selebihnya, atau $22,9 \%$, memaknai kata gahar dengan arti menggosok kuat-kuat, seperti yang terlihat dalam pilihan mereka dalam kalimat "Gahar pakaianmu Ahmad agar bersih!” seru ibu kepadaku. Dilihat dari konteks kedua kalimat tersebut, sangat jelas tergambar makna kata gahar pada masing-masing kalimat. Dengan melihat konteks tersebut, para responden, sebagian besar, memaknai keliru kata gahar. Para responden umumnya tidak melihat makna kata gahar dalam KBBI sehingga tidak sejalan dengan makna aslinya, tetapi lebih memaknainya sebagai akibat sering mendengar dalam kehidupan sehari-hari. Baik dalam obrolan, tulisan, bahkan sampai pada iklan-iklan dalam TV dan radio sering menggunakan makna garang pada kata gahar tersebut.

Selanjutnya, kata seronok, empek-empek, carut-marut, notulen, dan rempong, juga sebagian besar dimaknai keliru oleh responden, yaitu dimaknai dengan arti tidak senonoh sebanyak 62,9\%, makanan khas Palembang sebanyak 80\%, kekacauan sebanyak 74,3\%, petugas pencatat hasil rapat atau diskusi sebanyak 67,1\%, dan ribet atau ikut campur urusan orang lain sebanyak $70 \%$. Pemaknaan itu tergambar dari pilihan mereka pada kalimat “Aksi seronok yang dilakukan Ariel dan Luna Maya tidak patut untuk ditiru; Fikri adalah salah seorang pengusaha empek-empek yang sukses; Presiden Joko Widodo mengambil keputusan tegas dalam menghadapi carut-marut perpolitikan Indonesia; Dalam setiap diskusi, seorang moderator selalu didampingi oleh seorang notulen; dan Di 
dunia ini, banyak perempuan rempong yang suka mengurusi urusan orang lain”. Dilihat dari konteks kalimat-kalimat tersebut, sangat jelas tergambar makna kata-kata yang ada dan sebagian besar responden memaknainya secara keliru. Semua makna yang dipilih oleh sebagian besar responden tidak sejalan dengan makna dalam Kamus Besar bahasa Indonesia.

Khusus untuk kata notulen dan rempong, yang merupakan bentuk tidak baku dari notula dan rimpung, umumnya dimaknai dengan arti yang tidak bersumber pada bentuk bakunya. Notulen dimaknai sebagai petugas pencatat hasil rapat dan tidak sejalan dengan makna kata bakunya yakni notula yang bermakna catatan hasil rapat. Begitu pula pada kata rempong yang dimaknai repot atau ribet. Makna tersebut tidak sesuai dengan makna kata bakunya yakni rimpung yang bermakna terikat kakinya.

Berdasarkan dari persentase tersebut, kesalahan pemaknaan yang terjadi umumnya disebabkan oleh beberapa hal, antara lain: sering mendengar dari orang lain (masyarakat), melihat pada media, menjadi kebiasaan sehari-hari, dan melihat makna pada kamus. Penjelasan lebih lanjut mengenai penyebab-penyebab tersebut dipaparkan berikut ini.

\section{a. Sering Mendengar dari Orang Lain (Masyarakat)}

Umumnya, para responden memaparkan bahwa mereka memaknai beberapa kata yang diberikan dengan makna yang mereka peroleh dan berkembang di dalam masyarakat. Dari obrolan, dari tulisan yang mereka baca, dan lain-lain. Mereka jarang sekali menggunakan kamus sebagai acuan dalam memaknai kata-kata bahasa Indonesia. Mereka beralasan bahwa kamus sangat merepotkan ketika dijadikan acuan karena selain ukurannya besar dan tebal, kamus juga lumayan berat untuk dibawa. Padahal, saat ini telah tersedia kamus berbentuk mobile dalam smartphone dan dapat diperoleh secara gratis.

\section{b. Melihat pada Media (Cetak maupun Elektronik)}

Penyebab kedua pemaknaan yang hadir adalah sering melihat pada media massa, baik cetak maupun elektronik. Para responden, seperti pada penyebab pertama, jarang membuka kamus untuk mengecek makna kata. Mereka beralasan bahwa media pasti menggunakan kata dengan makna yang benar dan sesuai dengan makna dalam kamus, sehingga mereka tidak perlu lagi melihat pada kamus. Padahal, nyatanya terdapat beberapa media yang sering menggunakan kata dengan makna yang keliru. Ini banyak terjadi pada portal-portal berita online. 
Salah satu contohnya terdapat pada portal berita detiknews.com edisi 26 Agustus 2016. Dalam portal tersebut terdapat sebuah berita dengan judul "Menpan: Banyak PNS Datang ke Kantor Hanya untuk Absen Saja, Bukan Kerja”. Isi berita tersebut menggambarkan bahwa banyak PNS yang datang ke kantor hanya untuk menyetor atau mengisi daftar kehadiran dan tidak bekerja. Dari isi berita tersebut disimpulkan bahwa makna absen adalah mengisi daftar hadir. Makna tersebut tidak sejalan dengan makna dalam Kamus Besar Bahasa Indonesia.

\section{c. Menjadi Kebiasaan}

Penyebab ketiga hadirnya pemaknaan yang dilakukan oleh para responden adalah telah menjadi kebiasaan mereka memaknai kata seperti itu. Penyebab ketiga ini berhubungan erat dengan penyebab pertama dan kedua. Setelah menjadi kebiasaan, pemaknaan yang dilakukan pun sangat sulit berubah mengikuti pemaknaan yang benar sesuai dengan makna dalam kamus. Diperlukan pengubahan pola pikir kepada para responden agar lebih memaknai kata sesuai dengan makna dalam kamus.

\section{d. Melihat Makna dalam Kamus Besar Bahasa Indonesia (KBBI)}

Khusus untuk penyebab keempat ini, yaitu melihat makna pada kamus hanya dilakukan oleh empat responden yang semuanya adalah mahasiswa. Sangat disayangkan ketika peran kamus sebagai-landasan dan dasar pemaknaan kata tidak digunakan oleh sebagian besar atau seluruh responden dan hal ini perlu mendapat perhatian penuh dari seluruh pengguna bahasa Indonesia, baik pemerintah, melalui lembaga yang berwenang, maupun pendidik, dan masyarakat umum.

\section{Upaya Memperbaiki Penyalahkaprahan Makna}

Upaya yang dapat dilakukan untuk memperbaiki penyalahkaprahan makna tersebut yaitu dengan melalui revitalisasi bahasa Indonesia. Revitalisasi merupakan upaya untuk mengembalikan bahasa Indonesia kepada kaidah-kaidah yang benar dan sesuai dengan aturan yang berlaku (Sartini, 2014, hlm. 209). Upaya revitalisasi tersebut dapat dilakukan dengan beberapa cara, yakni meningkatkan kualitas bahasa para pendidik (guru dan dosen) di semua jenjang pendidikan, menumbuhkan sikap positif terhadap bahasa Indonesia, dan membuat aturan yang mengikat mengenai penggunaan bahasa Indonesia yang baik dan benar. 
Tidak berlebihan rasanya ketika kemampuan bahasa Indonesia para pendidik diharapkan tinggi karena di tangan merekalah proses pendidikan formal dimulai dan dari merekalah lahir kemampuan-kemampuan para peserta didik, yang salah satunya adalah bahasa. Subagyo (2011, hlm. 12) mengungkapkan bahwa pendidik menjadi men and women behind the gun yang menentukan keberhasilan pembelajaran bahasa Indonesia, baik ditingkat dasar, menengah, maupun di tingkat tinggi. Jadi, ketika mengharapkan kemampuan tinggi dari generasi penerus bangsa, maka terlebih dahulu kualitas pendidiknya harus meningkat. Kemudian, upaya memperbaiki penyalahkaprahan melalui pendidikan, khususnya peningkatan kemampuan guru dan dosen, juga penting karena pendidikan merupakan salah satu sarana untuk mempertahankan eksistensi bahasa Indonesia (Arifin, 2015, hlm. 85).

Selain itu, penumbuhan sikap positif terhadap bahasa Indonesia harus dilakukan dan ditingkatkan melalui penyosialisasian bahasa Indonesia yang benar, baik melalui seminar, kuliah umum, bahkan ketika berbincang-bincang dengan teman. Hal ini perlu mendapat perhatian yang lebih. Tidak perlu lagi minder mendengar ejekan teman ketika teman tersebut ditegur karena menggunakan bahasa Indonesia yang salah. Kita harus percaya diri demi tetap menjaga eksistensi bahasa Indonesia yang benar.

Lalu, yang terakhir, perlu ada tindak lanjut dari pihak yang berwenang dalam menanggapi fenomana penyalahkaprahan makna kata dalam bahasa Indonesia. Sangat diperlukan aturan yang mengikat pengguna bahasa Indonesia agar tetap menggunakan bahasa Indonesia sesuai dengan koridor atau kaidah yang berlaku. Aturan mengikat tersebut dapat berupa penetapan UKBI (Uji Kemahiran Berbahasa Indonesia) sebagai syarat bagi masyarakat yang akan menduduki kursi pemerintahan, menjadi pendidik, dan menjadi petinggi lainnya. sangat wajar ketika menetapkan aturan seperti itu karena aparat pemerintahan, pendidik, dan petinggi lainnya merupakan figur yang sering diperhatikan oleh masyarakat umum, bahkan tidak sedikit yang ditiru oleh masyarakat. Jadi, untuk membuat eksistensi bahasa Indonesia yang baik dan benar semakin meningkat, maka kemampuan berbahasa Indonesia bagi figur-figur tersebut harus tinggi.

\section{PENUTUP}

Pemaknaan kata bahasa Indonesia oleh pengguna bahasa Indonesia umumnya sebagian besar masih salah atau tidak sejalan dengan makna dalam kamus. Hal itu terlihat pada sebagian besar responden penelitian yang memaknai dua belas kata secara keliru. 
Kata-kata tersebut adalah acuh, bergeming, absen, absensi, nuansa, gahar, kosong, seronok, empek-empek, carut-marut, notulen, dan rempong. Umumnya, pemaknaan yang dilakukan oleh responden didasarkan pada kebiasaan sehari-hari, mendengar dari orang lain (masyarakat), melihat dan mendengar dari media, dan melihat makna dalam kamus. Namun, sangat disayangkan ketika hanya empat responden yang memaknai kata sesuai dengan kamus. Hal ini perlu mendapat perhatian khusus dari seluruh masyarakat pengguna bahasa Indonesia untuk membangkitkan kembali kedudukan kamus dalam memaknai kata.

Adapaun upaya yang dapat dilakukan untuk meminimalkan atau memperbaiki kesalahan pemaknaan itu dengan merevitalisasi bahasa Indonesia. Cara merevitalisasi bahasa Indonesia dilakukan dengan cara meningkatkan kualitas bahasa Indonesia para pendidik, menumbuhkan sikap positif terhadap bahasa Indonesia, dan menetapkan aturan yang mengikat bagi pengguna bahasa Indonesia agar menggunakan bahasa Indonesia yang baik dan benar. Salah satunya melalui penetapan UKBI sebagai standar pengakuan kemampuan berbahasa Indonesia.

\section{DAFTAR PUSTAKA}

Arifin, M. (2015). "Mempertahankan Bahasa Indonesia Sebagai Jati Diri Bangsa". Prosiding Seminar Nasional Bulan Bahasa UNIB (hlm. 82-87). Bengkulu: Penerbit FKIP UNIB.

Aslinda \& Syafyahya, L. (2010). Pengantar Sosiolinguistik. Bandung: Refika Aditama. Chaer, A \& Leonie, A. (2010). Sosiolinguistik Perkenalan awal. Jakarta : Rineka Cipta. Departemen Pendidikan Nasional. (2013). Kamus Besar Bahasa Indonesia Edisi Keempat. Jakarta: Gramedia Pustaka Utama.

Kementerian Pendidikan dan Kebudayaan Republik Indonesia. (2016). KBBI Daring. [Online]. Diakses dari https://kbbi.kemdikbud.go.id/Cari/Index.

Kridalaksana, H. (1985). Sikap dan Fungsi Bahasa. Flores: Nusa Indah.

Mahsun. (2005). Metode Penelitian Bahasa: Tahapan Strategi, Metode, dan Tekniknya. Jakarta: Raja Grafindo.

Moleong, L. J. (2005). Metodologi Penelitian Kualitatif. Edisi Revisi. Cetakan Keduapuluhsatu. Bandung: Remaja Rosdakarya.

Parera, J.D. (2004). Teori Semantik. Jakarta : Erlangga.

Sartini, N. W. (2014). Revitalisasi bahasa Indonesia dalam Konteks Kebahasaan. Masyarakat, Kebudayaan dan Politik, 27(4), 206-210.

Setyadi, A. (2014). Pemakaian Kompetitif: Macam Bidang dan Penyebab. Humanika, 20(2). 74-81.

Subagyo, P. A. (2011). Perkuliahan Bahasa Indonesia di Tengah Arus Global. Dalam S. Wiyanti \& Yulianeta (Penyunting), Bahasan dan Sastra Indonesia di Tengah Arus Global (hlm. 3-12). Bandung: Jurusan Pendidikan Bahasa dan Sastra Indonesia FPBS UPI. 
Sumarsono. (Penyunting). (2012). Pengantar Semantik. Yogyakarta: Pustaka Belajar.

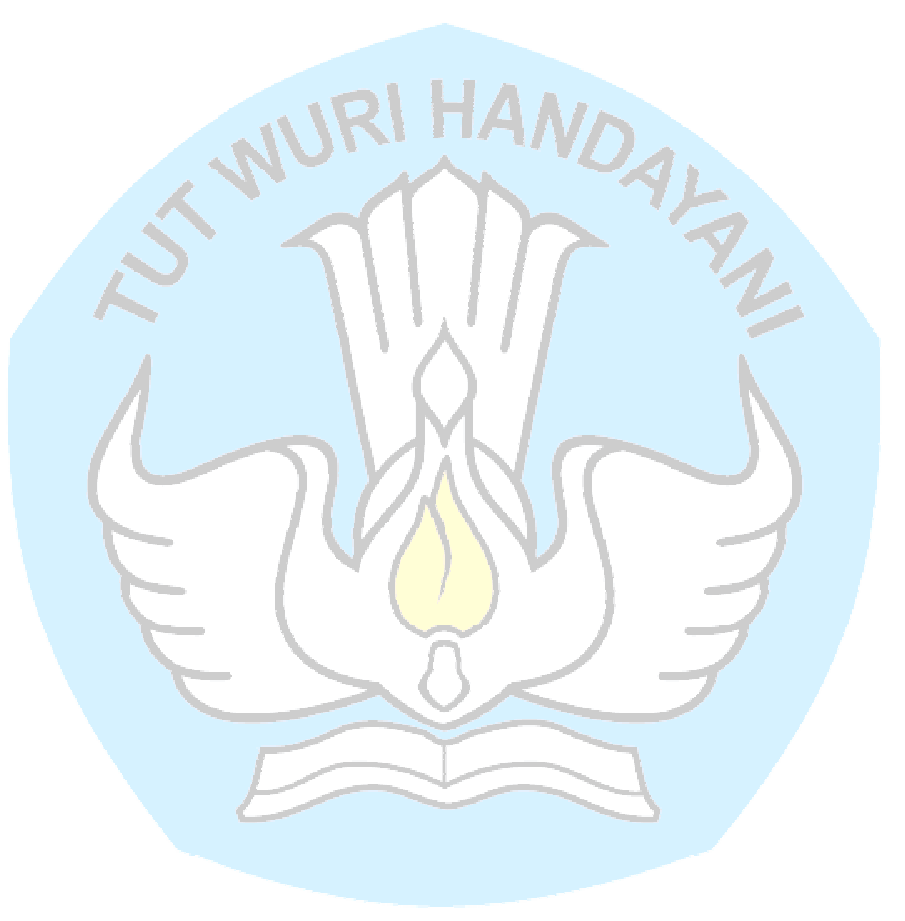

